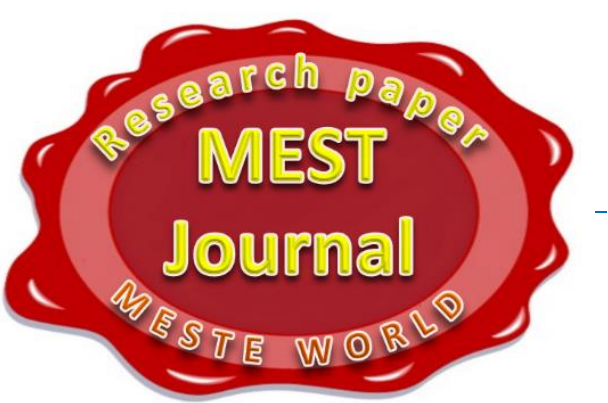

\title{
CRIME INDEX AS ONE OF THE MAIN INDICATORS OF SAFETY
}

\section{Roman Kmet}

University of Zilina, Faculty of Security Engineering, Zilina, Slovakia

\section{Zdenek Dvorak}

University of Zilina, Faculty of Security Engineering, Zilina, Slovakia

OMESTE

JEL Category: C88, L86

\begin{abstract}
The evolution of crime and its constant changes bring with it several new types of crime, which have many different crimes. By collecting and analyzing data in the form of these offenses, crime statistics are often generated for different periods of time or territorial units. The aim of these statistics is to divide the territory into smaller territorial units in which the level of crime is mutually assessed. For this purpose, a crime index has been created and is currently used to determine the level of crime in a territory. As crime is constantly developing and globalizing, it is necessary to modify this index to optimize and apply it in the European Union. Recently, security research has focused on crime index research. In the currently solved projects at the University of Zilina, creating a set of security indexes is one of the important challenges.
\end{abstract}

Keywords: safety, crime, the crime index

\section{INTRODUCTION}

Safety has always been an important factor in human existence. Humans try to protect their health, life, property and integrate into society in order to achieve a certain social status, on the basis of which he will respect and share one common space with him. Otherwise, certain social and legal norms and rules may be breached, which is the main essence of the crime.

Thus, crime is one of the key indicators of the security level of a certain area. Its status can be

\section{Address of the corresponding author:}

Roman Kmet

莑rroman.kmet@fbi.uniza.sk expressed by the crime index, which can be considered as an objective indicator of the state of crime.

\section{CRIME AS A SOCIAL- PATHOLOGICAL PHENOMENON}

Crime can be described as a negative social phenomenon that has legal, criminological, forensic, sociological, psychological and other aspects. It adversely affects the harmonious development of society. Spiritual and material damages to individuals or social groups are the result of violations of applicable laws, standards, moral values of society as the basis of crime (Gaspierik, 2010). 
By examining the different attitudes and views of the notion of crime, we can simply divide crime into two groups:

a) criminality understood as a crime,

b) criminality understood as behavior or conduct which, although not sanctioned but socially undesirable (Gasperik, 2010).

The state of crime can be described as an indicator of the safety of the local environment, which indicates a deterioration of the security situation in a specific location (Hofreiter, 2016).

\subsection{Crime structure}

Since crime concentrates many different antisocial behaviors, individual actions, it would not be right to label it as a monolithic one. Therefore, the following aspects are considered when assessing the structure of crime:

- type of crime,

- demographic aspect,

- urban aspect,

- territorial aspect (Hofreiter, 2004).

One of the main aspects of assessing the structure of crime is the type of crime. The aspect of crime type consists of specific types of crime (Molovcakova, 2018).

In the Slovak Republic, police statistics most often indicate the distribution of crime, which consists of:

- violent crime,

- moral crime,

- crime against property,

- economic crime.

As society evolves, crime also evolves, bringing with it several new types of crime, such as drugrelated crime and cybercrime (Hofreiter, 2004).
Given these divisions, the type of crime will be characterized by the species listed in the following table (Table 1), which presents the state of crime in the Slovak Republic for the year 2018.

Table 1 State of crime in the Slovak Republic for the year 2018

\begin{tabular}{|c|c|c|c|}
\hline $\begin{array}{c}\text { Type of } \\
\text { crime }\end{array}$ & $\begin{array}{c}\text { Registered } \\
\text { crimes }\end{array}$ & $\begin{array}{c}\text { Cleared } \\
\text { up crimes }\end{array}$ & $\begin{array}{c}\text { Clear-up } \\
\text { rate [\%] }\end{array}$ \\
\hline $\begin{array}{c}\text { Violent } \\
\text { crime }\end{array}$ & 5781 & 4413 & 76 \\
\hline $\begin{array}{c}\text { Moral } \\
\text { crime }\end{array}$ & 1122 & 735 & 66 \\
\hline $\begin{array}{c}\text { Crime } \\
\text { against } \\
\text { property }\end{array}$ & 21787 & 9545 & 44 \\
\hline $\begin{array}{c}\text { Other } \\
\text { crime }\end{array}$ & 7099 & 5609 & 79 \\
\hline $\begin{array}{c}\text { Economic } \\
\text { crime }\end{array}$ & 13515 & 6784 & 50 \\
\hline $\begin{array}{c}\text { Remaining } \\
\text { crime }\end{array}$ & 12088 & 10115 & 84 \\
\hline $\begin{array}{c}\text { Total } \\
\text { crime }\end{array}$ & $\mathbf{6 1 3 9 2}$ & $\mathbf{3 7 2 0 1}$ & $\mathbf{6 1}$ \\
\hline
\end{tabular}

Another aspect of crime structure assessment is the demographic aspect. The essence of this aspect is the application of different aspects such as:

- sex,

- age,

- the social or economic status of the offender, etc.

These aspects are used for statistical processing of crime and for the detection of the share of individual groups of offenders (Table 2) in committing crimes (e.g. minors, juveniles, persons intoxicated with alcohol or under the influence of drugs, etc.) (Hofreiter, 2016)

Table 2 Individual groups of offenders in the Slovak Republic

\begin{tabular}{|c|c|c|c|c|c|}
\hline \multirow[b]{2}{*}{ Type of crime } & \multirow{2}{*}{$\begin{array}{l}\text { Registered } \\
\text { crimes }\end{array}$} & \multicolumn{4}{|c|}{ Contributing factors } \\
\hline & & Alcohol & Drug & $\begin{array}{c}\text { Minor } \\
\text { offender }\end{array}$ & $\begin{array}{l}\text { Juvenile } \\
\text { offender }\end{array}$ \\
\hline Violent crime & 5781 & 1729 & 21 & 84 & 297 \\
\hline Moral crime & 1122 & 54 & - & 51 & 270 \\
\hline $\begin{array}{l}\text { Crime against } \\
\text { property }\end{array}$ & 21787 & 948 & 15 & 458 & 1357 \\
\hline Other crime & 7099 & 661 & 57 & 44 & 232 \\
\hline Economic crime & 13515 & 4729 & 63 & 9 & 80 \\
\hline Remaining crime & 12088 & 51 & 3 & 48 & 113 \\
\hline Total crime & 61392 & 8172 & 159 & 694 & 2349 \\
\hline
\end{tabular}


The urban aspect of crime assessment makes it possible to analyze the proportion of inhabitants of urban areas (towns, municipalities) in total crime and in individual types. Applying this aspect of crime assessment, we conclude that cities are riskier in terms of crime than smaller rural settlements (Hofreiter, 2016).

The accession of the Slovak Republic to the European Union and the need to adapt to the the methodology of the countries of this community was a standardized classification of territorial units for statistical purposes - NUTS (Nomenclature of territorial units for statistics) (Table 3). This system is a five-level hierarchical classification in which the NUTS I - NUTS III levels refer to the regional level (territory, area, region) and the LAU I (NUTS IV) - LAU II (NUTS V) levels refer to the local level (district, municipality) (Kmet, 2019).

Table 3 Standardized classification of territorial units in the Slovak Republic

\begin{tabular}{|c|c|c|c|c|}
\hline \multicolumn{5}{|c|}{ Level } \\
\hline \multicolumn{3}{|c|}{ Regional } & \multicolumn{2}{|c|}{ Local } \\
\hline NUTS I & NUTS II & NUTS III & LAU I (NUTS 4) & LAU II (NUTS 5) \\
\hline Country & Region & District & County - number & Municipalities - number \\
\hline \multirow{8}{*}{$\begin{array}{c}\text { Slovak } \\
\text { Republic }\end{array}$} & Bratislava & Bratislava & 8 & 73 \\
\hline & \multirow{3}{*}{ West Slovakia } & Trnava & 7 & 251 \\
\hline & & Trencin & 9 & 276 \\
\hline & & Nitra & 7 & 354 \\
\hline & \multirow{2}{*}{ Central Slovakia } & Zilina & 11 & 315 \\
\hline & & Banska Bystrica & 13 & 516 \\
\hline & \multirow{2}{*}{ East Slovakia } & Presov & 13 & 666 \\
\hline & & Kosice & 11 & 440 \\
\hline
\end{tabular}

Finally, it is necessary to mention the territorial aspect, which makes it possible to analyze the distribution of crime in a certain territory with a certain population by region (Hofreiter, 2004).

Specifically in relation to this aspect that we can come across a tool that compares crime in individual regions or locations - crime index,

which is common, used worldwide (Cekerevac, 2018).modification of crime index

The crime index is a quantitative indicator of crime, which expresses the ratio of the number of registered crimes $(R C)$ to the population of the surveyed location $(R)$ calculated per $N$ residents $(\mathrm{N}=1,000,10,000$ or 100,000$)$. Most often, a crime index is created, indicating the number of crimes detected per 100,000 residents (less than $1,000$ and 10,000$)$.

$$
C I=\frac{R C}{R} \times N
$$

$\mathrm{Cl}$ - crime index,

$\mathrm{RC}$ - registered crimes,

$\mathrm{R}$ - residents of the surveyed location,

$\mathrm{N}$ - residents $(1000,10000$ or 100000 .

In the Slovak Republic the statistics of the Ministry of the Interior, which are accessible to its residents, show absolute, not relative values what we can see in figure 1.

This results in distortion or deviation from the actual, real state of the crime level. 


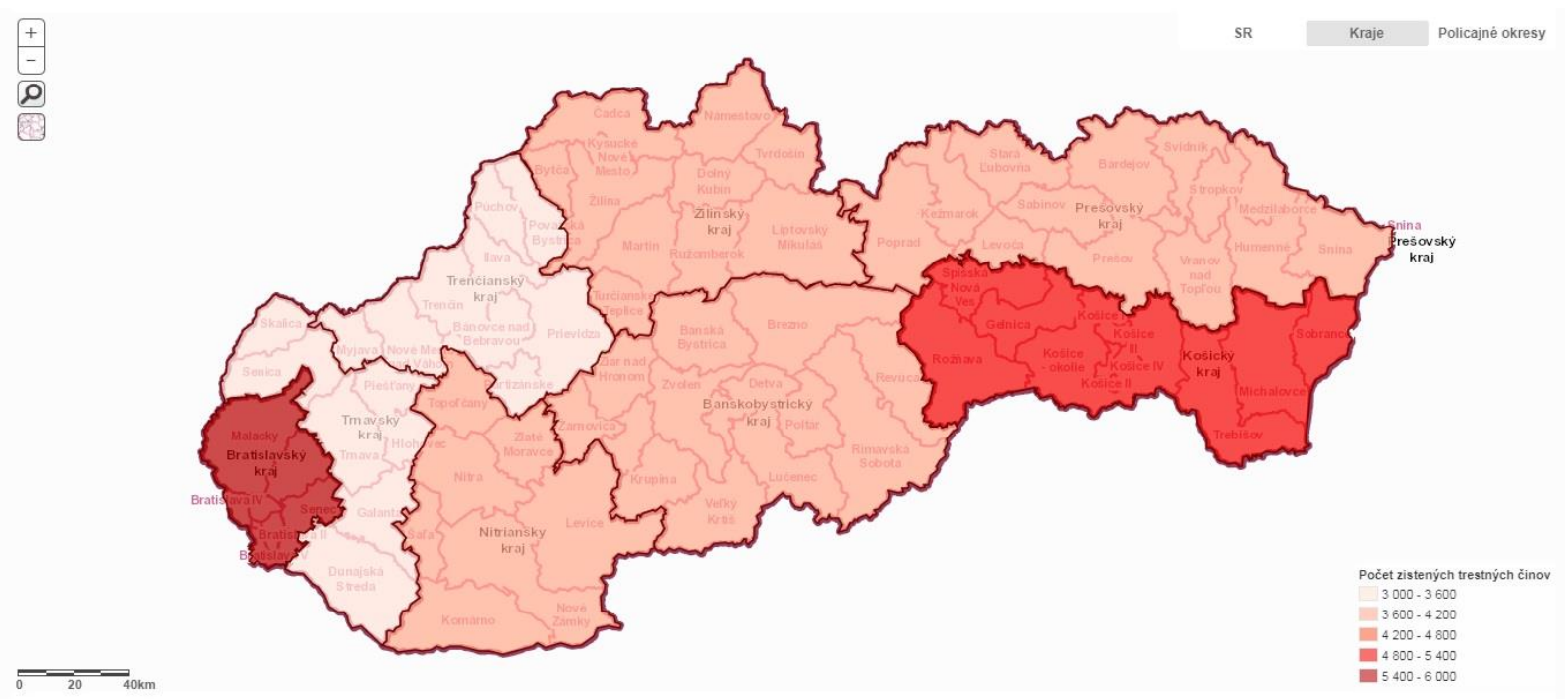

Figure 1 Number of detected crimes in the Slovak Republic in 2018 (Crime map, 2019)

When comparing absolute and relative values of in the order of individual regions in Table 4. crime (crime index) it is possible to see a change

Table 4 Order of individual regions of the Slovak Republic by crime

\begin{tabular}{|c|c|c|c|c|c|c|c|}
\hline District & $\begin{array}{c}\text { Number of } \\
\text { registered } \\
\text { crimes }\end{array}$ & $\begin{array}{c}\text { Criminality } \\
\mathbf{A}^{*}\end{array}$ & $\begin{array}{c}\text { Cleared } \\
\text { up } \\
\text { crimes }\end{array}$ & $\begin{array}{c}\text { Clear-up } \\
\text { rate [\%] }\end{array}$ & Residents & $\begin{array}{c}\text { Crime } \\
\text { index }\end{array}$ & $\begin{array}{c}\text { Criminality } \\
\mathbf{B}^{\star \star}\end{array}$ \\
\hline Bratislava & 10973 & $\mathbf{1}$ & 5163 & 47 & 659598 & 166 & $\mathbf{1}$ \\
\hline Trnava & 6396 & $\mathbf{7}$ & 3840 & 60 & 563591 & 113 & $\mathbf{3}$ \\
\hline Trencin & 5514 & $\mathbf{8}$ & 3415 & 62 & 585882 & 94 & $\mathbf{7}$ \\
\hline Nitra & 7380 & $\mathbf{3}$ & 4374 & 59 & 676672 & 109 & $\mathbf{5}$ \\
\hline Zilina & 7048 & $\mathbf{6}$ & 4744 & 67 & 691368 & 102 & $\mathbf{6}$ \\
\hline Banska Bystrica & 7169 & $\mathbf{4}$ & 4743 & 66 & 647874 & 111 & $\mathbf{4}$ \\
\hline Poprad & 7138 & $\mathbf{5}$ & 4883 & 68 & 825022 & 87 & $\mathbf{8}$ \\
\hline Kosice & 9543 & $\mathbf{2}$ & 5875 & 62 & 800414 & 119 & $\mathbf{2}$ \\
\hline
\end{tabular}

* Criminality A - Order of districts in the Slovak Republic by registered crimes

${ }^{* *}$ Criminality B - Order of districts in the Slovak Republic by the crime index

Currently, we can observe differences in the crime indexes of individual European Union countries. As the Slovak Republic is a part of it, our effort and task will be to modify and optimize the crime index within the Slovak Republic with possible use in the other EU Member States (Soltes, 2018).

\section{Scales of individual crimes}

It is necessary to determine the scales of individual crimes first. A growing number of new crimes arise with a growing society. Some have a lesser impact on society or the individual and some have a greater impact. Therefore, when assessing crimes, account should be taken of:

- consequences:

- no bodily harm,

- minor bodily harm,

- serious bodily harm,

- death,

- number of the concerned person,

- the amount of damage. 
The values of these three indicators should form the basis for determining the weight of the crime.

\section{Criminally liable residents}

The crime index includes residents of the area where the crime occurs. It is very important that only residents who are criminally responsible are counted in this index.

\section{Residents without permanent residence}

The crime index should include all residents of the area under consideration, including residents without permanent residence of that area. This is mainly because these people can also be involved in creating crime. Above all, these are larger cities in which there is a massive turnover of either the incoming employees of local companies or tourists.

\section{Assessed area}

At present, the main deficiency of the crime index is the area under review. Police districts or regions are too large areas to create security measures to reduce crime. The same is true from the perspective of the resident who is trying to find out the level of crime in his place of residence. One example is the high level of crime in the Žilina Region in 2018.

For example, a citizen living in Rajec falling under the Zilina region with a high crime rate in 2018, even though no crime was recorded in that city this year. This may mislead or misrepresent citizens' views of safety or the level of crime.

\section{Number of $\mathbf{N}$ residents}

Individual EU countries recalculate the crime index per 1000,10000 or 100000 residents. It is important to establish a uniform value for the potential confrontation of individual EU countries.

\section{Determination of critical thresholds}

The crime index represents the determination of the crime level of the selected territory. This index should include a critical threshold indicating a site with a high crime level, where security measures must be taken as a matter of priority to bring the crime level below the critical threshold.

\section{EXPLOITATION OF CRIME INDEX IN PRACTICE}

Part of the initial version of the crime map project of the selected region is also the crime index.

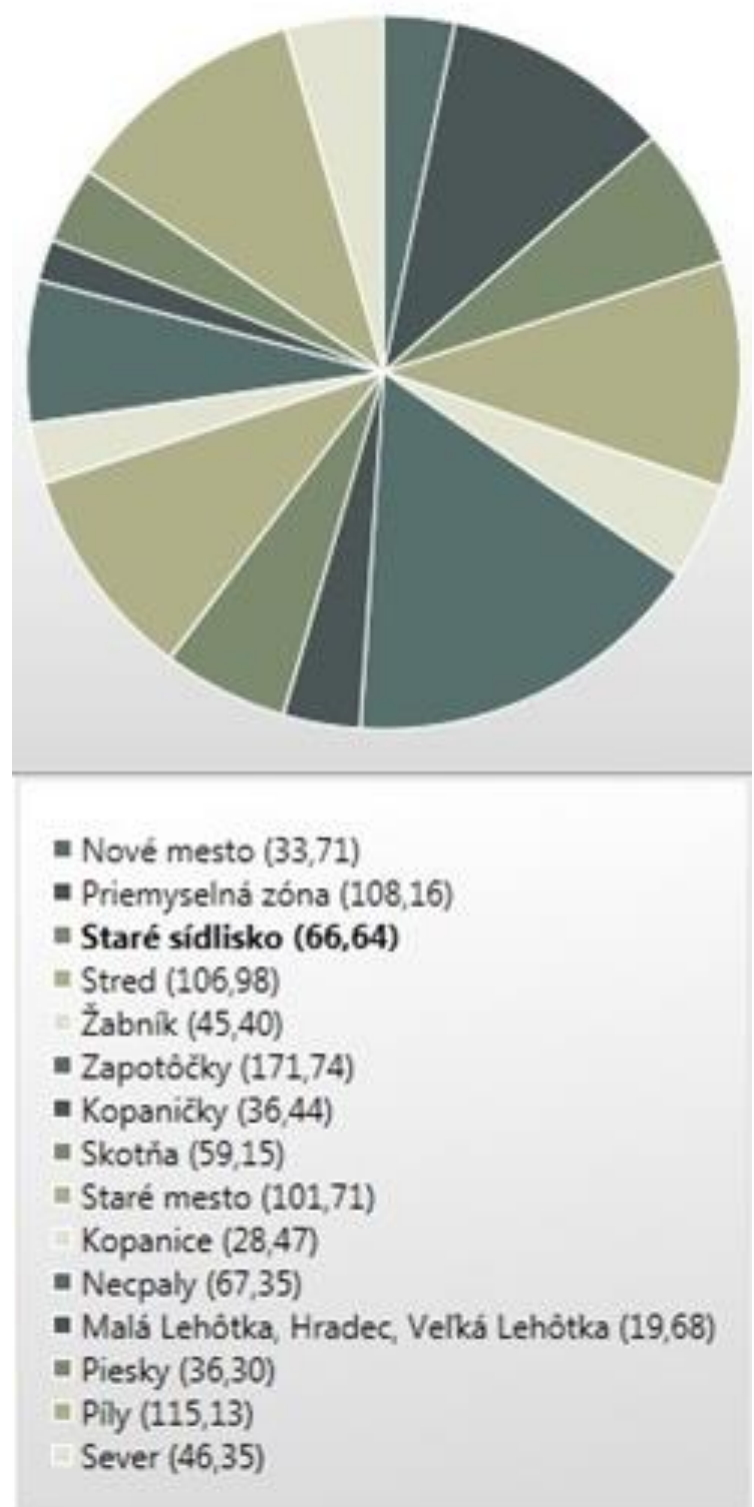

\section{Medium crime index}

\section{Number of crimes: 43}

Figure 2 Crime index for 2018

Its display is represented by a pie chart in the application along with a list of individual locations of the selected region (Figure 2). After a resident has selected a specific location using a filter, he must choose a time period for which he will see the crime index, either year or year and month. 
Subsequently, all sites of the selected region with the corresponding crime index will be displayed in this section. If a resident moves the mouse over each part of the pie chart, he will also see the crime index of that location (Kmet, 2018).

The crime index indicator subsection shows the level of crime, which can be rated as low, low to medium, medium to high or high, based on the value of the crime index (Figure 2). Each level of crime is assigned a different color. The resident can use this indicator to find out the level of crime in the selected location and compare it with the level of crime in other locations for a certain period (Kmet, 2018).

This part also includes the number of crimes of the selected location.

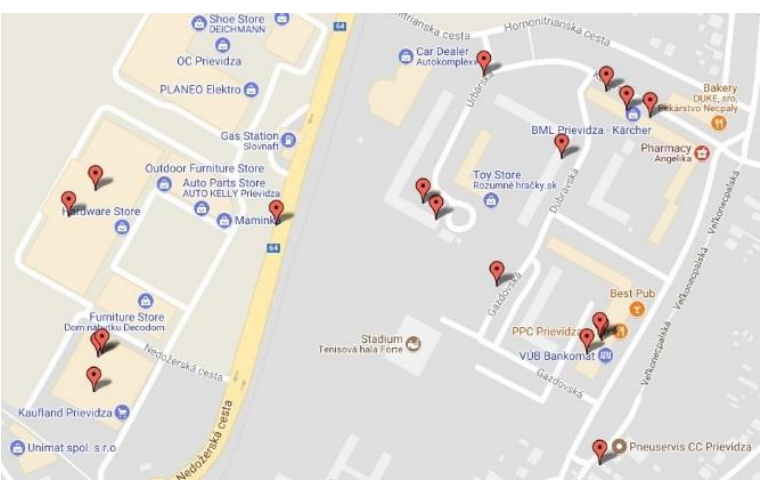

Figure 3 Display of crimes of the selected location on the map

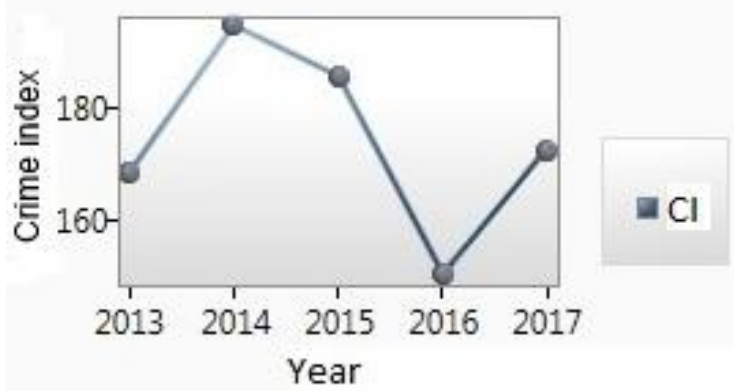

Figure 4 Evolution of the crime index in the selected region

Through the crime index, we can follow the evolution of crime levels over time (Figure 4). The evolution of the crime index may be focused on the year or month of each location of the selected region. This is an indication for the resident of how crime levels have developed over the past few years in specific locations in the selected region. Using this indicator, we can determine whether the level of crime in each location tends to increase or decrease. We can also identify months in which the level of crime is increased.

The result of modifying the crime index is the optimization and greater objectification of the crime status analysis of the selected region. This allows us to identify locations as priorities in designing, creating and applying measures to reduce crime levels or predict crime levels for the future.

\section{DISCUSSION OF RESULTS}

The crime index is important for theoretical research and is also very important for practice. In practical use in the Slovak Republic, the Police of the Slovak Republic presents only absolute numbers of crimes by district and region. If the total number of crimes is recalculated to the number of inhabitants of the locality examined, it is not possible to make a ratio comparison. For a citizen, the relative state of crime is more interesting than the absolute number of crimes.

On the theoretical level, it is possible to create different ratios. Currently, researchers have focused on modifying the crime index. We perceive the scales of individual crimes as key. Their definition must be based on real research and be as objective as possible.

Researchers found these weights:

- extensive questionnaire investigations,

- personal consultations with experts on crime issues,

- brainstorming in crime workshops,

- obtaining relevant information from abroad,

- working with researchers at home and abroad.

Effective communication with the Police of the Slovak Republic and obtaining real information is a serious problem in objectifying the scales of individual crimes of the Crime Index. Currently used police information systems cannot be used in real research. The only way is to collect selected data from the police information system through personal consultations. In the future, it would be appropriate to create a superstructure of the police information system, which will export the anonymized data and thus be available for research. 


\section{CONCLUSION}

Crime analysis is part of every major city in Europe. It can result in crime statistics that show a certain level of crime in a given territory. These areas are most often police districts or higher territorial units (regions). The shortcoming of this statistic can be identified just the territory, which is too large to create concrete measures to increase security or reduce crime. Another drawback can be the resulting statistics data, which show the number of crimes of a certain territory without these crimes converted to population. This brings with it misleading, distorted information provided to residents.
That is why our focus has led to the crime index, which is currently the only objective indicator of crime levels that are used across European countries. If we look at the states of the European Union, the values that are part of the crime index vary. In order to optimize and make it more objective, this index needs to be set up so that it is uniform for all EU countries so that the state of the crime of these states can be compared. The modified crime index should include the creation of scales for individual crimes, less space to be assessed, the inclusion of only criminally responsible residents as well as residents who do not reside in the surveyed area and, finally, the determination of threshold values.

\section{WORKS CITED}

Cekerevac, Z., Dvorak, Z., Prigoda, L., \& Cekerevac, P. (2018). Hacking, protection, and the consequences of hacking (Review). Communications - Scientific Letters of the University of Zilina, (2/2018), 83-87.

Gaspierik, L. (2010). Prevention of crime and other anti-social activity. Kosice: MULTIPRINT, p. 11. ISBN 978-80-970410-0-7

Hofreiter, L. (2004). Security, security risks and threats. First edition. Zilina: EDIS, s. $99-106$. ISBN 808070-181-4

Hofreiter, L., \& Byrtusova, A. (2016). Safety indicators. First edition. Zilina: EDIS, s. 23 - 93. ISBN - 97880-87500-82-8

Kmet, R., 2018. Crime map of Prievidza. Diploma thesis. Zilina: FBI UNIZA.

Kmet, R., Dvorak, Z., \& Kvet, M. (2019). Map of traffic accidents. International Scientific Conference on Sustainable, Modern and Safe Transport, TRANSCOM 2019. Code 150446

MVSR (2019, Sep.) Statistika kriminality v Slovenskej republike za rok 2019. Ministerstvo Vnutra Slovenskej Republiky. Retrieved September 13, 2019, from https://www.minv.sk/?mapy_trestnych_cinov_v_slovenskej_republike_za_rok_2019

Molovcakova, N., Velas, A., KuraJ, M., \& Kucera, M. (2018). Reducing crime by using modern technology in the chosen city. In: Training, education, and management: proceedings of 2018 5th ICMIBI international conference. - 1. pub. - Singapore: Singapore Management and Sports Science Institute, 2018. ISBN 978-981-11-8187-0. p. 153-156

Soltes, V., \& Kubas, J. (2018). Investigation of crime in a regional security environment. In: Crisis situation solving in a specific environment 2019. 1. pub. Zilina: UNIZA, 2018. ISBN 978-80-5541439-3. - p. 356-365

\section{Acknowledgment}

This paper was supported by institutional grant project UNIZA - Information system for evaluating the level of crime of a selected region 
Received for publication: $\quad$ 13.09.2019

Revision received: $\quad 28.12 .2019$

Accepted for publication: $\quad 10.01 .2020$

\section{How to cite this article?}

Style - APA Sixth Edition:

Kmet, R., \& Dvorak, Z. (2020, January 15). Crime index as one of the main indicators of safety. (Z. Cekerevac, Ed.) MEST Journal, 8(1), 57-64. doi:10.12709/mest.08.08.01.07

Style - Chicago Sixteenth Edition:

Kmet, Roman, and Zdenek Dvorak. 2020. "Crime index as one of the main indicators of safety." Edited by Zoran Cekerevac. MEST Journal (MESTE) 8 (1): 57-64. doi:10.12709/mest.08.08.01.07.

Style - GOST Name Sort:

Kmet Roman and Dvorak Zdenek Crime index as one of the main indicators of safety [Journal] // MEST Journal / ed. Cekerevac Zoran. - Belgrade - Toronto : MESTE, January 15, 2020. - 1 : Vol. 8. pp. 57-64.

Style - Harvard Anglia:

Kmet, R. \& Dvorak, Z., 2020. Crime index as one of the main indicators of safety. MEST Journal, 15 January, 8(1), pp. 57-64.

Style - ISO 690 Numerical Reference:

Crime index as one of the main indicators of safety. Kmet, Roman and Dvorak, Zdenek. [ed.] Zoran Cekerevac. 1, Belgrade - Toronto : MESTE, January 15, 2020, MEST Journal, Vol. 8, pp. 57-64. 